\title{
OPEN
}

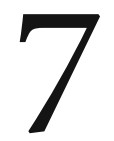

\section{From Responsible to Responsive}

Abstract: To what extent do companies and business leaders have responsibilities that go beyond looking after the economic interests of their owners and shareholders? This chapter investigates that question in the light of a story about the owner of an Icelandic fishing company, who has to decide whether to maintain activity on four locations in the country, or downsize to one location, which appears to be the best solution from an economic perspective. The owner can analyse his alternatives using the Navigation Wheel, or he can apply Archie Carroll's two models, one focusing on levels of corporate responsibility and another identifying corporate responsiveness. The former model distinguishes between legal, economical, ethical, and philanthropic dimensions of responsibility, while the latter conveys how a decision-maker in business can choose between four response levels: Reaction, defence, accommodation, and pro-action. The Icelandic fishing story serves as an illustration of what these alternative perspectives can mean in a concrete and practical setting.

Kvalnes, Øyvind. Moral Reasoning at Work: Rethinking Ethics in Organizations. Basingstoke: Palgrave Macmillan, 2015. DOI: 10.1057/9781137532619.0009. 
Hjalti is the CEO of Farsæll, a fishing company in Iceland. The fallen price of cod and haddock in the international markets and fierce competition from Norway and other countries are making it difficult for Farsæll to run the five fishing vessels and four fish processing plants located around Iceland. The company has activities in Djúpavogur in the east of the country, Húsavík in the north, Pingeyri in the west fjords, and in Grindavík in the south west. Increasing demands from the buyers of fish products for a flexible product portfolio and shorter time to market is also hard to handle with the current business setup.

Hjalti is pondering the suggestion from the chairman of the board to close down three of the four fishing plants and concentrate on one location. It will give Farsæll more productivity and flexibility, as well as much lower labour cost. He also knows that their fish processing plants are vital to the local communities where they operate. If they close down the plants, up to $50 \%$ of the local work force will lose their jobs, not counting the related jobs his operations create in supporting companies.

A recent article in the newspaper reported about another Icelandic fishing company that had just paid out high dividends to its owners. The reaction was very negative and the journalist accused the owners of running away from their social responsibilities. The company had received the fishing quota for free from the government, based on the national policy to support those companies and investors who promise to operate in small communities around the country and create jobs. Those jobs are very poorly paid, so the value of the quotas seems to go all in the pockets of the owners. The press is likely to be even more negative if Hjalti decides to close the Farsæll plants around the country, since that move will be even more dramatic than the one of not sharing profits with the low paid workers.

The situations reminds Hjalti of the words of his father, who never tired of telling him how he grew up in Pingeyri and took over the family fishing company after having lost his father, Hjalti's grandfather, at the age of 11. Hjalti's father always said that Pingeyri and the small communities are the heart of the company. They gave them short access to the fishing grounds and a steady and loyal work force. Hjalti knows many of these people by name and he knows that they will not have other income opportunities if he decides to close down the plants permanently.

Hjalti experiences considerable moral unease and dissonance at the thought of closing down the three fishing plants. The decision will negatively affect many people, and due to his personal history and the history 
of his company, he feels responsible for the outcome for the employees and the local communities. One alternative he considers is to sell the whole company to an investor. He knows that this investor immediately will close down the plants and downsize dramatically. The outcome for the population will be the same, but at least it will not be Hjalti's decision. He has to choose one of three alternatives: Either continue as before with all four fishing plants, downsize to one plant, or sell the entire company to an investor, who will rationalize the setup and close three plants.

The Icelandic philosopher Ketill Berg Magnússon and I have designed the story about Hjalti and his company, and we have used it in the teaching of business school students. We have asked the students to analyse Hjalti's alternatives using the Navigation Wheel, and in their eyes, the main conflict is between the company's values and identity and Hjalti's moral convictions on the one hand, and the economic aspects on the other. There are no legal obstacles to stop Hjalti from closing down the plants, but that in itself does not equip him with a reason to do it. As we saw in the previous chapter, the fact that there are no laws against a particular course of action, does not in itself constitutes a reason for choosing it. Company values and personal moral convictions are closely entwined in this case, since Farsæll is a family enterprise that has developed over generations, based on shared family values regarding community and building up activity together. Hjalti is also likely to be concerned about his own reputation, both in the country as a whole, and in the local communities in particular, and in the short and long term. Of course, he does not want to be remembered and labelled as the person who put a stop to social life in the three affected locations. On the other hand, Hjalti must also take economic realities seriously. He has obligations towards family members to keep the company profitable and secure economic stability for future generations bearing his name.

Corporate social responsibility is also a dimension of the Icelandic story. To what extent are decision-makers in business responsible for the outcomes of their decisions, beyond looking after the shareholders' and employers' financial interests? One approach can be based on the dictum that the business of business is business, a claim attributed to Milton Friedman. There is insufficient textual support to claim that Friedman actually wrote or said this, but he clearly opposed the idea that business leaders should take upon themselves any other responsibilities than the ones of generating profitable activity (Friedman, 1962; Friedman, 1970). He claimed that "there is one and only one social responsibility 
of business - to use it resources and engage in activities designed to increase its profits so long as it stays within the rules of the game, which is to say, engages in open and free competition without deception or fraud" (Friedman, 1970). From Friedman's perspective, then, Hjalti should choose the economically best alternative, which appears to be to close down three fishing plants and concentrate the activity on one remaining plant.

Archie Carroll has presented models to analyse the social responsibility of companies (Carroll, 1979; Carroll, 1991). One of them distinguishes between economic, legal, ethical, and philanthropic dimensions of decision-making, and is similar to the Navigation Wheel in that it offers a framework for analysis of alternatives and options. One difference is that Carrol provides a ranking of his four dimensions, in that the economic and legal are required of the decision-maker, while the ethical is expected, but not required, and the philanthropic considerations are desired, but neither expected nor required. Applied to Hjalti's situation, the model indicates that he is required to respect the restrictions of law, and to make economically sound decisions, while he is only expected to take ethical aspects of the situation into account in his decision-making. If he decides to be philanthropic and place the concerns for society at the forefront, he acts in a manner that is desired from a societal perspective, but that goes beyond what is required legally and economically, and also beyond what can reasonably be expected of him.

In a second model, Carroll distinguishes between four ways in which decision-makers in business can respond to social issues that occur in connection with their activities. Responsiveness is a more actionoriented conceptualization than the one focusing on responsibility. Decision-makers in business can be in a position where they have identified a social issue, and their corporate social responsiveness can be reaction, defence, accommodation, and pro-action (Carroll, 1979, p. 501). The first of these responses - reaction - is to deny any responsibility and claim that it is up to the government or other institutions to remedy the problem. The defence response consists of reluctantly accepting and taking some minimal responsibility, but mainly for reputational purposes, to demonstrate a societal concern that it can be beneficial to show towards other stakeholders. If there are no reputational benefits to reap from taking an initiative, the company should remain passive, according to this line of thinking. The third response is accommodation, and it involves listening to affected stakeholders in the situation, and to 
experts in the field of dealing with such issues, taking up their advice about how to deal with it. Finally, the pro-action response is one where the decision-makers go beyond industry norms and expectations, and shows innovation in coming up with unexpected and brilliant solutions to the challenges at hand.

Even Carroll's responsiveness model offers input to Hjalti and the decision he faces. He can choose reaction, and claim that it is not his responsibility as a business owner to uphold activities in remote parts of Iceland. It is the politicians and the local and national authorities who should address that issue. Hjalti can go for defence, and become minimally engaged in what happens in the local communities once his plants are closed down, or he can involve experts in an accommodation effort to identify how a company like his can contribute to social development in remote communities in Iceland, following their advice. Finally, he can choose pro-action, and explore ways to generate activities in those communities, making them less dependent on the fishing traditions of old. He can offer the fishing plant facilities for free or for a very low price to entrepreneurs and innovators who can generate other kinds on employment in the communities. He can collaborate with education providers, who can help his employees to identify and pursue alternative careers. All may not be bleak, even though the employment in fishing disappears.

It is worth noting that one of the alternatives that Hjalti considers, of selling the company and leaving the dirty work of closing down the plant to others, is another course of action where utilitarianism and duty ethics will offer conflicting advice to the decision-maker. The utilitarian focuses on the outcome of the alternatives, and since they in all relevant senses appear to be the same, it would not be better, or less worse, for Hjalti to sell and leave the unpopular decision to others. Whether he directly or only indirectly causes this painful outcome for the local community, is morally irrelevant from a utilitarian perspective.

An evaluation from a duty ethics perspective, on the other hand, can claim that there is a morally relevant difference between what a person does, and what he or she merely lets happen. We are primarily responsible for what we decide actively to do, and not so much for what we are passive witnesses to, even though we may have been in a position to stop that from happening. Duty ethics also gives emphasis to intention, and as noted in Chapter 3, the Doctrine of Double Effect distinguishes between intended outcomes and outcomes that are merely foreseen 
and unfortunate side-effects of a decision or course of action. Hjalti can claim that his intention is to make sure the company is profitable, and not to hurt the local communities. Duty ethics, then, relieves Hjalti of at least some of the moral burden of either closing down the plants himself or leaving that to an investor. This ethical theory provides him with the opportunity to wash his hands, and claim that the negative outcome is merely foreseen and not intended. Utilitarianism offers a more stern perspective, since it dismisses both the active - passive distinction, and the distinction between intended and foreseen outcomes.

Corporate social responsibility and responsiveness are areas where business leaders and employees have to engage in moral reasoning, in order to clarify to themselves and others where their priorities should lie. It is one thing to agree in general that companies and individuals in business have social responsibilities, and another to agree upon concrete measures and activities in concrete cases. People, who disagree in general about the scope and content of the social responsibilities of companies, may agree in particular cases about what a company should do. Furthermore, people who agree that corporate social responsibility matters and deserves to be high on the agenda, may disagree fiercely in particular cases about what a company should do under those given circumstances. It is by exploring cases like the one involving Hjalti and his decision about the future of his fishing activities that we can go from comparing personal moral intuitions and gut feelings to seeing the principled dimensions of the roles of business in society.

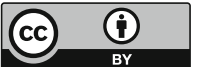

Except where otherwise noted, this work is licensed under a

Creative Commons Attribution 3.0 Unported License. To view a copy of this license, visit https://creativecommons.org/licenses/by/3.0/ 